\begin{tabular}{rr} 
çaḡdaş & Yaratıcı Drama Dergisi 2016, 11(1), 105-116 \\
drama & www.yader.org \\
\hline
\end{tabular}

\title{
İngilizce Sözcük Gruplarının Öğretilmesinde Yaratıcı Drama Yönteminin Etkisi*
}

\author{
Şerife Demircioğlu ${ }^{1}$ \\ Oylum Akkuş İspir ${ }^{2}$
}

\begin{tabular}{|c|c|c|}
\hline \multicolumn{2}{|c|}{ Makale Bilgisi } & $\ddot{\mathbf{O} z}$ \\
\hline \multicolumn{2}{|c|}{ DOI: $10.21612 /$ yader.2016.007 } & $\begin{array}{l}\text { Bu çalışmanın amacı, Ingilizce sözcük gruplarının öğretiminde yaratıcı dramanın } \\
\text { ögretim yöntemi olarak kullanılmasında katılımcıların sözcük ögrenimi açsından }\end{array}$ \\
\hline \multicolumn{2}{|c|}{ Makale Geçmişi } & olumlu bir fark yaratıp yaratmadı̆̆ını belirlemektir. Bu amaç doğrultusunda 2011- \\
\hline Geliş tarihi & 18.01.2016 & 2012 eğitim ögretim yılında Ankara'da bulunan Gazi Üniversitesi Vakfi Özel \\
\hline Düzeltme & 17.05 .2016 & $\begin{array}{l}\text { Ilkokulu'nda 3. sinıfta okuyan } 16 \mathrm{klz} \text { ve } 12 \text { erkek olmak üzere toplam } 28 \text { öğrenci } \\
\text { ile } 18 \text { saat süren atölye çalışmaları yapılmıştır. Araştırmada nicel araştırma }\end{array}$ \\
\hline Kabul & 30.05 .2016 & $\begin{array}{l}\text { desenlerinden deneme öncesi modelin kullanılması uygun görülmüştür. Deneme } \\
\text { öncesi modellerden "tek grup ön test- son test desen" deseni kullanılmıştır. Veri }\end{array}$ \\
\hline \multicolumn{2}{|c|}{ Anahtar Sözcükler } & $\begin{array}{l}\text { toplama araçları olan sözcük grupları başarı testleri, ögrrenci ürünleri ve izleme } \\
\text { testinden elde edilen bulgulara göre, Ingilizce sözcük gruplarının ögretiminde }\end{array}$ \\
\hline \multicolumn{2}{|c|}{ Ingilizce öğretimi } & yaratıcı dramanın bir yöntem olarak kullanılmasının ögrencilerin sözcük bilgileri \\
\hline \multicolumn{2}{|c|}{ Sözcük grupları öğretimi } & üzerinde olumlu bir etkisi olduğu söylenebilir. \\
\hline \multicolumn{3}{|c|}{ Yabancı dil öğretimi } \\
\hline \multicolumn{3}{|c|}{ Yaratıcl drama } \\
\hline \multicolumn{3}{|c|}{$\begin{array}{c}\text { The Effect of Creative Drama as a Method on Teaching English Word } \\
\text { Clusters }\end{array}$} \\
\hline \multicolumn{2}{|c|}{ Article Info } & Abstract \\
\hline \multicolumn{2}{|c|}{ DOI: $10.21612 /$ yader.2016.007 } & $\begin{array}{l}\text { The aim of the study is to determine whether the effect of creative drama as a } \\
\text { method to teach English word clusters to young learners has a positive effect. The }\end{array}$ \\
\hline \multicolumn{2}{|c|}{ Article History } & study was carried out in Gazi University Foundation Private Primary School in \\
\hline Received & 18.01 .2016 & $\begin{array}{l}\text { the implementations was } 18 \text { hours in total. In the study, as a quantitative research } \\
\text { the }\end{array}$ \\
\hline Revised & 17.05.2016 & design, the pre-experimental research was used. One group pre-test-posttest design \\
\hline Accepted & 30.05 .2016 & $\begin{array}{l}\text { was preferred. When the findings of the research study obtained from achievement } \\
\text { tests for word clusters, the formative test and students' products were examined, it } \\
\text { can be claimed that teaching English word groups via creative drama as a method }\end{array}$ \\
\hline \multicolumn{2}{|c|}{ Keywords } & has a positive effect on young learners'lexical knowledge. \\
\hline \multicolumn{3}{|c|}{ Creative Drama } \\
\hline \multicolumn{3}{|c|}{ English language teaching } \\
\hline \multicolumn{3}{|c|}{ Foreign language education } \\
\hline \multicolumn{3}{|c|}{ Teaching word clusters } \\
\hline
\end{tabular}

\footnotetext{
* Bu çalışma MEB Özel Doğaç Yaratıcı Drama Liderliği/Eğitmenliği Projesi’nden geliştirilmiş̧tir.

1 Dr., Gazi Üniversitesi, İngiliz Dili Eğitimi, E-posta: serifeaydogan@yahoo.com

2 Doç. Dr., Ohlone Üniversitesi, E-posta: oyluma@hacettepe.edu.tr
} 


\section{Giriş}

Son y1llarda çocuklar için İngilizce öğretimine olan ilgi giderek artmaktadır. Küçük yaşta dil öğretiminin yetişkinlere olan dil öğretiminden daha etkili olduğu düşünülmektedir. Çünkü İngilizcenin bir çocuğa ve bir yetişkine öğretilmesinde birçok farkl11ık vardır. Yetişkinlerle karşılaştırıldığında çocuklar çok daha heveslidir ve hareketlidir. Sebebini ve nasıl yapılacağı çok iyi anlamasalar da aktivitelere katılma istekleri daha fazladır. Fakat ilgilerini çok çabuk kaybedebilirler (Cameron, 2001). Bu yüzden, çocukların hareket edebilecekleri, öğrendikleri şeye odaklanabilme sürelerini etkin tutabilecekleri bir öğrenme ortamının ve bunları sağlayabilecek bir öğretmen yaklaşımının olması gerekmektedir. Otoriter bir öğretmen yaklaşımı öğrencinin kendi dünyasını anlaması için çok az olanak sağlamaktadır: Otoriter yaklaşımlarda çocuklar sessizce otururken öğretmen konuşur ve çocuklara söz hakk1 verildiğinde çocuklar sadece öğretmenlerinin onlara öğrettiklerini söyleyebilmektedirler (Sierra,1997). Bu yüzden çocuklara İngilizce öğretiminde, öğretmenlerin farklı yöntem ve teknikler kullanarak sınıfta farklı bir atmosfer yaratmaları gerekmektedir. $\mathrm{Bu}$ atmosferin yaratılmasında ve çocukların İngilizceyi öğrenmesinde kullanılan yöntemlerden biri İngilizce öğretiminde yaratıcı dramanın kullanılmasıdır.

Geleneksel eğitim sisteminde İngilizce sözcük öğretiminde öğrencinin edilgen, öğretmenin etkin olduğu alışagelmiş yöntemler kullanıldığı sıklıkla gözlenmektedir. Ancak, böyle bir ortamda çocuk sadece sözcükleri ezberlemekten öteye gidememektedir. Bilgiyi içselleştiremediği için, öğrenilenleri sınıf dışında kullanamamaktadır. Çocuk yeterli dilbilgisine sahip olsa da sözcük haznesindeki yetersizlikten dolayı iletişime geçememektedir. Öğrencilerin pasif sözcük hazneleri vardır, yani sözcükleri gördüklerinde anlamını söyleyebilir, fakat sözcükleri kullanamadığ 1 için aktif hale getiremezler. Bu yüzden yabancı dilde sözcük öğretimine bakış açısı çeşitli aşamalar geçirmiştir ve sözcüklerin bir yapı içinde bir anlam bütünlüğü ile öğretilmesinin daha yararlı olacağı üzerinde durulmuştur (Demirel, 2004). Carter ve McCarthy'nin (1988, s. 11) de söylediği gibi "Dilbilgisi olmadan çok az şey ifade edebiliriz ama sözcükler olmadan hiçbir şey ifade edemeyiz”.

Yaratıcı drama yoluyla yapılandırılan dersler, öğrencilere zihinsel, fiziksel ve duygusal katılım yoluyla, aktif bir ortamda var olma olanağı sunmaktadır. Gerçek hayatta dili kullanma ve iletişime geçebilme, fikirleri ve duyguları içermektedir. Başka bir deyişle, bir ortamda uygun bir tümce ya da sözcük kullanımını gerektirmektedir. Yaratıcı dramada çocuklar bir bağlam içerisinde İngilizceyi öğrendikleri ve birçok kez kullanma fırsatı bulabildiği için İngilizceyi günlük hayata geçirmede çok daha az zorluk yaşayacaklardır. "Yaratıcı drama yüz ifadeleri, beden hareketleri gibi sözel olmayan iletişimi de kullanarak çocukları, İngilizce bilgileri çok az olsa da, konuşma ve iletişime geçme konusunda cesaretlendirir" (Philips, 1999, s. 65).

McCaslin'in (1990, s. 88) ifade ettiği gibi yaratıcı drama, "çocukların farkındalığını arttırmak, hayal yoluyla gerçeğe bakabilmelerini sağlamak ve yüzeysel hareketlerin altındaki anlamları görmelerini sağlamak” için kullanılır. Başka bir deyişle, çocuklar çevrelerindeki olayların farkına varır, olayların sebeplerini anlamaya çalışır ve problemler için farklı çözüm yolları bulur. Bütün bunları yaparken kendi yaşantılarından yola çıkarlar.

Çocuklar dildeki diğer becerilerle beraber özellikle sözcük öğretiminde yaratıcı dramanın kullanılmasından farklı şekillerde yararlanmaktadır. Çocuklar sözcüklerin anlamını bilseler bile, sözcükleri tümcede ya da uygun ortamlarda kullanamamakta ve bunun sonucunda artık İngilizce öğrenmek çocuklar için bir yük haline gelmektedir. Fakat yaratıcı drama ile yapılandırılmış bir 
derste çocuk sözcükleri tek tek öğrenmez ya da ezberlemez. Sözcükler bir süreç içerisinde verilir ve bu sürece çocuk zihinsel ve duygusal olarak katılır. Öğrenme "sonuçtan çok sürece odaklıdır ve yaşantıların çoğu drama alanında kendiliğinden (spontan olarak) yaşanır" (Adıgüzel, 2006, s. 23). Birbirleriyle etkileşim halinde olan ve hayal gücünü kullanan öğrenciler aktif katılımcılardır. Yaratıcı drama yöntemiyle sınıfta ezberlenmesi gereken belirli sözcüklerin üzerine yoğunlaşmaktan daha eğlenceli etkinliklere doğru yöneliş, dil sınıflarındaki anlamayı ya da üretmeyi normal olarak engelleyen gerginliği azaltır (Ritterberg \& Kreitzer, 1981). Bunun sonucunda öğrenciler öğrenme sürecinden keyif alıp kendilerini baskı altında hissetmezler. Çocuklar sözcükleri farkında olmadan öğrenirler ve içselleştirirler çünkü çocuklar sözcüklerin anlamını ve sözcüklerin yüklediği duyguyu yaşayarak öğrenirler (Sinatra, 1983). Aynı zamanda sözcükleri öğrenirken biriyle iletişime geçme konusunda kullanacağı konuyu değiştirme, konuşma sırasını bilme gibi iletişim becerilerini de geliştirirler (Whiteson, 1996).

Yaratıcı dramanın yabancı dil öğretiminde kullanılmasına ilişkin yapılan çoğu çalışmada anlamlı sonuçlar çıkmıştır. Örnek verilecek olursa; Aynal'ın (1989) dramatizasyon yönteminin yabancı dil öğretimini üzerine etkisi, Dupont'un (1989) 5. sınıf öğrencilerinin okuma becerilerinin iyileştirilmesinde yaratıcı dramanın yöntem olarak kullanılması, Gaudart'ın (1990) dil öğretiminde drama tekniklerinin kullanılması, Hamilton'ın (1993) dil sınıflarında drama, Karamanoğlu'nun (1998) İngilizce öğretiminde yaratıcı drama uygulamalarının hedef sözcük bilgisi ve hatırlamaya etkisi, Çıtak'ın (2003) drama yoluyla çocuklara İngilizce dilbilgisi öğretimi, Özbahar'ın (2007) yaratıcı drama ile İngilizcede sözcük öğretimi gibi çalışmalarda yaratıcı drama yöntemiyle yapılan uygulamalarda istatistiksel olarak sözcük öğretiminde, dilbilgisi öğretiminde ve okuma becerilerinin geliştirilmesinde yaratıcı drama uygulamaları lehine anlamlı bir fark görülmüştür.

Yaratıcı dramanın sağladığı birçok avantaj olmasına rağmen, İngilizce öğretmenleri yaratıcı dramayı derslerinde kullanmanın avantajlarından yeteri kadar yararlanmamaktadırlar. İlk olarak, birçok İngilizce öğretmeni yaratıcı dramanın tiyatroyla aynı olduğunu ya da derslerde sadece diyalog çalışmalarının yaratıcı drama olduğunu düşünmektedirler. Birçok yabancı dil programında yaratıcı drama ile ilgili dersler olmadığı için ve dolayısıyla (Furman, 2000) öğretmen bu konuda yetkin olmadığı için, dramayı öğrencilerine öğretmenin geçerli bir nedenini görmemektedirler (Dodson, 2000).

Ayrıca öğretmenler derslerinde yaratıcı dramayı kullandıkları zaman sınıflarında kargaşanın ve gürültünün kaçınılmaz olduğu kanısındadırlar. Bu yüzden yaratıcı drama ile yapılandırılmış bir dersin çok dikkatli planlandırılması ve öğrencileri her zaman aktif tutan, yaratıcılığa yönlendiren etkinlikler içermesi gerekmektedir. "Bütün öğrencilerin aktif katılımcılar olduğu bir sınıfta, drama çalışmaları kargaşanın az olduğu ve ürüne dayalı çalışmaların olduğu oturumlar haline gelir” (Flynn \& Carr, 1994, s. 16). Ayrıca öğrenci yaratıcı drama etkinlikleri sırasında kendi kendini disipline edebilmeyi öğrendiği için sınıf içi kargaşası zamanla azalacaktır (Erion, 1997).

Bunun yanı sıra, öğretmenin lider, yönetici ve aktör gibi farklı rolleri vardır ve bu rolleri aynı anda yürütür. Öğretmenin birden fazla rolünün olması ve bu roller sırasında öğretmen ve öğrenci arasındaki engellerin ortadan kalkması öğretmenlerin yaratıcı dramaya karşı olumsuz tavır geliştirmesindeki diğer sebeplerinden biridir. Bütün bu sebeplerden dolayı, kendine daha az güveni olan öğretmenler yaratıcı dramayı bir yöntem olarak kullanma konusunda isteksizlerdir. Fakat Dorothy Heathcote'un (1972, s.76) ifade ettiği gibi, “öğretmenlerimizi, uzmanlık bilgilerini ellerinde 
tutarak, öğretmenin vereceği bilgiye ulaşmadan önce öğrencilerine problemlerle başa çıkmaları için olanaklar yaratmaları, öğrencilerin neler yapacağını dinlemeden kendi yaptığı işten yola çıkarak cevaba ulaşmaları konularında eğitmeliyiz". Böylelikle öğrencinin bilgiye ulaşma isteğini arttırmış ve öğrenci öğrenme sürecine doğru yüreklendirilmiş olur.

Sonuç olarak, öğrencilerin yaş grubu özelliklerine göre öğrendikleri sözcükleri pasif halden aktif hale getirmeleri ve öğrendikleri sözcükleri içselleştirip günlük hayatta kullanabilmeleri için İngilizce sözcük gruplarının yaratıcı drama yöntemiyle öğretilmesi gerekmektedir.

\section{Çalıșmanın Amacı}

$\mathrm{Bu}$ çalışmanın amacı, İngilizce sözcük öğretiminde yaratıcı dramanın öğretim yöntemi olarak kullanılmasında katılımcıların sözcük gruplarını öğrenimi açısından olumlu bir fark yaratıp yaratmadığını belirlemektir.

\section{Yöntem}

\section{Araştırmanın Modeli}

$\mathrm{Bu}$ araştırma, nicel araştırma desenlerinden "deneme öncesi model”e göre tasarlanmıştır. Deneme öncesi modellerin ortak özelliği, desende iç geçerliği tehdit eden faktörlerin kontrol edilmemesi ve seçkisizliğin söz konusu olmamasıdır. Deneme öncesi modeller dörde ayırmaktadır ve bu çalı̧̧mada “tek grup ön test- son test desen” kullanılmıştır. Bu desende tek bir deney grubuna ön test uygulanır, uygulama yapıldıktan sonra da son test uygulanır. Seçkisizlik ve eşleştirme yoktur. Elde edilen sonuç ön test ve son test ölçümlerinin farkıdır. Bu modelde gelişigüzel seçilmiş bir gruba bağımsız değişken uygulanır (Büyüköztürk, Çakmak, Akgün, Karadeniz ve Demirel, 2009).

\section{Çalışma Grubu}

Bu çalışma, 2011- 2012 eğitim-öğretim yılında, Gazi Üniversitesi Vakfı Özel İlköğretim Okulu 3. sınıfta okuyan 9 yaşında olan 16 kız ve 12 erkek olmak üzere toplam 28 öğrenciyle yürütülmüştür. Bu öğrenciler haftada 1 saat yaratıcı drama dersi ve 7 saat İngilizce dersi görmektedir.

\section{Veri Toplama Araçları}

Araştırmaya ilişkin verilerin toplanması amacıyla her biri araştırmacı tarafindan hazırlanan "Sözcük Grupları Başarı Testleri”, "Öğrenci Ürünleri Kontrol Listeleri” ve "İzleme Testi” kullanılmıştır.

\section{Sözcük Grupları Başarı Testleri}

Sözcük grupları başarı testleri, araştırmaya dâhil edilen öğrencilerin her bir oturum sonrası öğrenme düzeylerini ortaya koymak amacıyla hazırlanmıştır. Başarı testleri geliştirilirken bilgi ve kavrama düzeylerini ölçmeye yönelik sorular öğrencilerin dönem özellikleri dikkate alınarak hazırlanmıştır. Testler genellikle resimle sözcügü eşleştirme ya da resmin yanına sözcüğü yazma gibi soruları içermektedir. Her bir oturumun amacına göre ayrı ayrı oluşturulan yedi test için kapsam geçerliği bağlamında üç uzmandan görüş istenmiş, alınan görüşler doğrultusunda testlere son hali verilmiştir. 


\section{Öğrenci Ürünleri Kontrol Listeleri}

Gerçekleştirilen 3., 4., 6. ve 7. oturumlarda yapılan yaratıcı drama etkinliklerinin canlandırma ve değerlendirme aşamalarında öğrenciler tarafından ortaya konulan poster, çalışma kağıtları ve gazete ürünlerinde, öğrenme düzeyini belirlemek amacıyla kontrol listeleri hazırlanmıştır.

\section{İzleme Testi}

İzleme testi, gerçekleştirilen drama uygulamalarının tamamlanmasının ardından, söz konusu oturumlarda öğrenilen sözcük gruplarının kalıcı olup olmadığının test edilebilmesini sağlamak amacıyla hazırlanmıştır. Test, her bir oturumda öğretilen sözcükleri içerecek şekilde yedi bölümden oluşmuştur. Bu testte resimle sözcüğü eşleştirme, sözcüğü verilen boşluğa yazma, bulmaca içinde sözcüğü bulma, harfleri karışık verilen sözcügü bulup yazma, sözcüğün baş harfinin verilip geri kalanın yazılması gibi farklı soru sorma teknikleri kullanılmıştır.

\section{İşlem}

Çalışma; 2011- 2012 eğitim-öğretim yılında, Gazi Üniversitesi Vakfi Özel İlköğretim Okulu 3. sınıfta okuyan 28 öğrenciyle anasınıfı ahşap ev salonunda toplam 18 saat süren 8 oturumda uygulanmıştır. Her oturum öncesinde öğrencilerin sözcük gruplarına ilişkin bilgisini ölçmek amacıyla öğretilmesi hedeflenen sözcük gruplarını içeren bir başarı testi yapılmıştır. Aynı başarı testi oturum sonrasında öğrencilere tekrar uygulanmıştır.

Her bir oturum için yedi ya da sekiz sözcüğü içeren bir sözcük grubu oluşturulmuştur: hayvanlar, kıyafetler, duygular, fiiller, hava durumu, oyuncaklar ve ülkeler gibi. Her bir oturum içeriğinin oluşturulmasında Adıgüzel'in (2002) yaratıcı drama aşamalarından (hazırlık-ısınma/ canlandırma/ değerlendirme) yararlanılmıştır. Bu aşamaların içerisine sözcük öğretimi aşamaları (sunum, pratik, üretim) entegre edilmiştir. Sözcük grupları tek tek değil, bir bağlam içerisinde öğretilmiştir.

Hazırlık/ 1sınma aşamasında Cotrell (1987)'in de belirttiği gibi öğrencilerin grupla etkin bir iletişim içerisinde olacağı bir sınıf atmosferi yaratılmıştır. Ayrıca bu aşamada öğretilmesi hedeflenen sözcükler sunulmuş, bu sözcüklere yönelik etkinlikler yapılmış ve sözcük grupları öğretilmiştir. Canlandırma aşamasında, hem öğrencilerin grup çalışması yapabilmesi hem de hazırlık/ısınma aşamasında öğrendikleri sözcükleri kullanabilmelerine yönelik etkinlikler yapılmıştır. Aşamalar arasında yapılan ara değerlendirmeler yardımıyla öğrencilerin öğretilmesi hedeflenen sözcük gruplarını öğrenip öğrenmedikleri anında yoklanmıştır. Son aşama olan değerlendirme aşamasında, öğrencilerin yapılan çalışmayı değerlendirmesi, ayrıca bireysel ya da grup olarak öğrendikleri sözcükleri kullanabilecekleri ürünler ortaya koymaları istenmiştir. Oturumlarda yaratıcı drama tekniklerinden rol oynama, doğaçlama, pantomim, rol içinde yazma, donuk imge gibi teknikler kullanılmıştır. Örnek bir oturum planı EK 1'de verilmiştir.

7 atölye çalışması yapıldıktan sonra 8. oturumda genel bir değerlendirme çalışması yapılmış ve 8 . oturumdan bir ay geçtikten sonra öğretilen sözcüklerin ne kadarının hatırlandığını görme amacıyla bir izleme testi uygulanmıştır. Tüm süreç öğrenci ve veli izni alınarak kamera altına alınmıştır. 


\section{Verilerin Analizi}

Sözcük grupları başarı testlerinden toplanan veriler, bilgisayar ortamına aktarılarak SPSS 17.0 istatistik paket programı yardımıyla değerlendirilmiştir ve Wilcoxon işaretli sıralar testinin kullanılması tercih edilmiştir. Öğrenci ürünlerinin değerlendirilmesinde kontrol listesi kullanılmıştır. İzleme testinin değerlendirilmesinde aynı örneklem üzerinde aynı test ile 3 kez ölçüm alındığı için "ilişkili ölçümler tek faktörlü varyans analizi”nin non-parametrik karşıllı̆̆ olan "Friedman testi" kullanılmıştır.

\section{Bulgular ve Yorum}

Bu kısımda veri toplama araçlarından sözcük grupları başarı testleri, izleme testi ve öğrenci ürünlerinden elde edilen bulguların açıklanmasına ve yorumlanmasına yer verilmiştir.

\section{Sözcük Grupları Başarı Testleri}

$\mathrm{Bu}$ çalışmada verilerin normal dağılım göstermemesi nedeniyle Wilcoxon işaretli sıralar testinin kullanılması tercih edilmiştir. Çocukların yaratıcı drama uygulamaları öncesi ve sonrası öğretilen sözcük bilgilerinde anlamlı bir farklılık gösterip göstermediğine ilişkin Wilcoxon işaretli sıralar testi sonuçları aşağıdaki tabloda verilmiştir.

Tablo 1. Ön test-Son test Sözcük Bilgisi Testi Puanlarının Wilcoxon Işsaretli Stralar Testi Sonuçları

\begin{tabular}{lccccccc}
\hline Öntest-Sontest & & & & \multicolumn{4}{c}{$\begin{array}{c}\text { Ön Test- } \\
\text { Son Test }\end{array}$} \\
\hline & $\mathrm{n}$ & $\bar{X}$ & Min. & Max. & ss & $\mathrm{z}$ & $\mathrm{p}$ \\
\hline Ön Test & 28 & 25.6 & 12 & 40 & 5.54 & & \\
\cline { 2 - 8 } Son Test & 28 & 40.7 & 33 & 44 & 2.70 & $-4.62 \mathrm{a}$ & .000 \\
\hline
\end{tabular}

a. Negatif sıralar temeline dayalı

Tablo 1'deki analiz sonuçları incelendiğinde çalışmaya katılan çocukların yaratıcı drama uygulama öncesi (X: 25.6; SS: 5.54) ve uygulama sonrası sonrası (X:40.7; SS: 2.70) aldıkları puanlar arasında anlamlı bir fark vardır $(\mathrm{z}=-4.62, \mathrm{p}<.0 .5)$. Başka bir deyişle, sonuçların son test puanı lehinde olduğu görülmektedir. Bu sonuçlara göre İngilizce sözcük gruplarının öğretiminde yaratıcı dramanın bir yöntem olarak kullanılmasının öğrencilerin sözcük bilgileri üzerinde olumlu bir etkisi olduğu söylenebilir.

\section{Öğrenci Ürünlerinin Değerlendirilmesi}

Oturumlar boyunca öğrencilerden hazırlamaları istenen posterler, çalışma kağıtları, gazeteler belirlenen kazanımların ürünlere yansıması ve oturumlar sonunda kendilerinde neler kaldığını belirlemek amacıyla değerlendirilmiştir. Bu ürünler aşağıda detaylı bir şekilde verilmiştir.

\section{Posterler}

Öğrenciler 3. oturumun değerlendirme aşamasında canlandırmalarla ilgili duygularını öğrendikleri İngilizce sözcüklerle ve resimlerle ifade etmişlerdir. Yapılan poster incelendiğinde öğrencilerin tamamının İngilizce sözcükleri doğru kullandıkları görülmüştür. 4. oturumun canlandırma 
aşamasında öğrenciler robot posterlerini yaparken öğrendikleri sözcüklerin \%90'ını doğru bir şekilde kullanabilmişlerdir. 6. oturumda öğrenciler kendi oyuncak müzelerinin posterini hazırlamışlardır. Öğrenciler posterlerini hazırlarken İngilizce sözcüklerinin \%90’ını doğru kullanabilmişlerdir.

\section{Çalışma Kâğıtları}

Öğrencilere değerlendirme aşamaları boyunca öğretilen sözcükleri içeren bulmacalar ve çalışma kağıtları verilmiştir. Öğrenciler bunları bireysel ya da eşleriyle yapmışlardır. Öğrencilerin bulmaca kağıtları ve çalışma kağıtları incelendiğinde sözcüklerin \%90'ının öğrenildiği yönünde bir değerlendirme yapılmıştır.

\section{Gazete Çalışması}

7. oturumda oturumda öğrencilere sözcük grupları verilmiş ve öğrenciler bu sözcük gruplarıyla ilgili bir gazete yapmışlardır. Gazeteler incelendiğinde çocukların İngilizce sözcüklerin hepsini doğru kullandıkları gözlenmiştir.

\section{İzleme Testi}

8 oturum bittikten sonra ve son yapılan oturumun üzerinden bir ay geçtikten sonra öğrenilen sözcüklerin kalıcılığını ölçmek amacıyla izleme testi uygulanmıştır. Aynı örneklem üzerinde aynı test ile 3 kez ölçüm alındığı için "ilişkili ölçümler tek faktörlü varyans analizi”nin non-parametrik karşılığı olan "Friedman testi” kullanılmıştır.

Tablo 2. Friedman testi sonucu

\begin{tabular}{lccccc}
\hline & $\mathrm{N}$ & $\mathrm{X}$ & $\mathrm{Ss}$ & Min. & Max. \\
\hline Ön test & 28 & 25.68 & 5.54 & 12.00 & 40.00 \\
\hline Son test & 28 & 40.72 & 2.70 & 33.00 & 44.00 \\
\hline İzleme testi & 28 & 35.60 & 6.23 & 20.00 & 43.00 \\
\hline
\end{tabular}

Tablo 3. Ön test- son test- izleme testi istatistiğ $i$

\begin{tabular}{ll}
\hline $\mathrm{N}$ & 28 \\
\hline Chi-Square & 48.45 \\
\hline Df & 2 \\
\hline Asymp. sig. & .00
\end{tabular}

Tabloya göre $(p<.0,5)$ küçük olduğu için ortalamalar arasında anlamlı bir fark vardır. Fakat hangi ortalamalar arasında anlamlı bir fark olduğunun belirlenmesi için ölçümlerin ikili karşılaştırmalarına (ön test-son test, ön test-izleme testi, son test-izleme testi) Wilcoxon işaretli sıralar testi uygulanmıştır.

Tablo 4. Wilcoxon İşaretli Siralar Testi Sonuçları

\begin{tabular}{lrrr}
\hline & Öntest- sontest & Öntest -İzleme testi & Sontest- İzleme Testi \\
\hline $\mathrm{Z}$ & $-4.62 \mathrm{a}$ & $-4.62 \mathrm{a}$ & $-3.78 \mathrm{~b}$ \\
\hline $\begin{array}{l}\text { Asymp. sig. } \\
(2-t a i l e d)\end{array}$ & .00 & .00 & .00 \\
\hline
\end{tabular}


Wilcoxon testi post-hoc testi olarak kullanıldığı için, yani hangi iki ortalama arasında fark olduğunun belirlenmesi amacıyla, anlamlılık düzeyi olarak " $\alpha /$ karşılaştırma sayısı" alınır (Field, 2005, s.557). Bu durumda anlamlılık düzeyi olarak 0.05/3=0.01 alınır ve karşılaştırmalardaki sig değerleri bu değerle karşılaştırılır. Tablo 4'deki p değerlerine bakıldığında $(Z=4.62, p<.0 .5)$, $(\mathrm{Z}=4.62, \mathrm{p}<.0 .5),(\mathrm{Z}=3.78, \mathrm{p}<.0 .5)$ sonuçların hepsi arasında anlamlı bir fark vardır. Test sonuçları arasında anlamlı bir fark olduğu için yaratıcı drama yöntemiyle sözcük gruplarının öğretiminin etkili bir yöntem olduğu söylenebilir.

\section{Sonuç}

Son yıllarda çocuklara İngilizce öğretimine ilgi giderek artmaktadır ve bu konuda başarılı olmak amacıyla birçok yöntem kullanılmaktadır. Bu yöntemlerden en etkili olanlarından birinin yaratıcı drama yoluyla İngilizce öğretimi olduğu söylenebilir.

$\mathrm{Bu}$ çalışmada da yaratıcı dramanın öğrencilere sağladığı bütün avantajlar düşünülerek ilkokul 3.sınıf İngilizce dersinde sözcük gruplarının öğretiminde yaratıcı dramanın bir öğretim yöntemi olarak kullanılması ve bu yöntemin sözcük gruplarının öğretiminde etkisinin ne olduğu araştırılmıştır. Bulgular incelendiğinde uygulama öncesi ve sonrası puanlar arasında anlamlı bir fark çıkmıştır.

Öğrencilerin başarılı olmasında birçok neden gösterilebilir. Öğrencilere uygulanan son testlerde ve 1 ay sonra uygulanan izleme testindeki başarının en büyük kaynağı, yaratıcı drama yöntemiyle öğretilen sözcüklerin bir bağlam içinde öğretilmesidir. Öğrencilere bir sözcük listesi gösterilip ezberlenmesi istenmemiş, aksine öğrenciler aktif bir şekilde derse katılarak sözcüğü duyarak, kullanarak kısacası yaşayarak öğrenme fırsatı yakalamışlardır. Böylelikle öğrenciler sözcüğü içselleştirme sürecini yaşamışlardır. Öğrenciler farklı duyularını kullanarak sürece katıldıkları için sözcüğün uzun süreli belleğe geçmesi hızlanmıştır (Pincotti, 2000).

Ek olarak, öğrenciler grup halinde çalışmışlardır. Her biri bir grubun üyesi olduğu için öğrenciler kendi sorumlulukları kapsamında çalışmışlar ve birbirine yardım etmişlerdir. Böylece öğrencilerin motivasyon süreleri uzamış ve sürekli aktif olmuşlardır. Sonuçta, öğrenciler bilgiyi birlikte inşa etmişlerdir. Grup çalışmasının sağladığı diğer bir yarar da, öğrencilerin arkadaşlık ilişkilerinin gelişmesidir. Öğrencilerin önce kendilerine daha sonra arkadaşlarına güvenleri artmıştır. Ayrıca öğrencilere kendilerindeki yeni olanaklarını aramaları için firsat sağlamıştır (Yassa,1999). Buna ek olarak, birbirlerinin farklı yönlerini görmüş ve yaratıcılığın hazzını beraber yaşamışlardır. $\mathrm{Bu}$ da olumsuz akran baskısını ortadan kaldırmış ve öğrenciler farklı riskler alabilmişlerdir.

Son olarak, geleneksel yöntemlerin tersine yaratıcı drama yöntemiyle sözcük gruplarının öğretimi öğrencilerin yeni sözcükler öğrenmeye karşı olumlu bir tavır sergilemesine yardımc1 olmuştur. Öğrenciler; oturumlar boyunca eğlendikleri için, derste aktif rol oynadıkları ve kendilerine sunulan bilgiyi değil kendi inşa ettikleri bilgiyi kullandıkları için atölye çalışmalarından büyük keyif almışlar ve her oturuma istekli bir şekilde katılmışlardır. 


\section{Öneriler}

Yapılan bu çalışmada İngilizce sözcük gruplarının öğretiminde yaratıcı dramanın bir yöntem olarak kullanılmasının olumlu bir etkisi olduğu bir kez daha ortaya konmuştur. Çalışmanın sonuçları doğrultusunda şu öneriler yapılabilir;

1. Program geliştirme uzmanlarının ve kitap yazarlarının İngilizce sözcük gruplarının öğretiminde yaratıcı dramanın yöntem olarak kullanıldığı örnek ders planlarının, kitaplara eklenmesi önerilmektedir.

2. Sınıf ortamında yaratıcı drama oturumlarını uygulamak çok zor olduğundan, okul idaresi İngilizce öğretmenleri için ayrı bir drama odası sağlayabilir. Ayrıca uygulamalarda kullanılacak CD çalar, boya kalemleri, kartonlar gibi bazı materyaller de bu odada bulundurulmalıdır.

3. Bu çalışma 3. sınıfa giden 28 öğrenci ile yapılmıştır. Küçük yaş grubu öğrencilerle yaratıcı drama uygulamaları yapılırken grubun daha küçük tutulması hem sınıf yönetimi hem de etkinliklerin daha rahat yapılması açısından önemlidir.

4. Küçük yaş grubu öğrenciler canlandırmalara hazırlanmaları aşamasında planlanan zamandan daha fazla zamana ihtiyaç duyabilirler. Bu yüzden oturumun bitirilmesi planlanan zamandan daha fazla sürenin verilmesi önerilmektedir.

\section{Kaynakça}

Adıgüzel, Ö. (2002) Eğitim bilimlerinde ve sanat eğitiminde yöntem, disiplin ve sanatsal boyutlarıyla yaratıcı drama. 11. Eğitim Bilimleri Kongresi, Yakın Doğu Üniversitesi, KKTC.

Adıgüzel, Ö. (2006). Yaratıcı drama kavramı, bileşenleri ve aşamaları. Yaratıcı Drama Dergisi, 1, 17-31.

Aynal, S. (1989). Dramatizasyon yönteminin yabancı dil öğretimini üzerine etkisi. Yayımlanmamış yüksek lisans tezi, Çukurova Üniversitesi Eğitim Bilimleri Enstitüsü, Adana.

Balcı, A. (2007). Sosyal bilimlerde araştırma yöntem, teknik ve ilkeler. Ankara: Pegem Yayıncılık.

Büyüköztürk, Ş., Çakmak,E. K, Akgün, Ö.E., Karadeniz, Ş. ve Demirel, F. (2009) Bilimsel araştıma yöntemleri, Ankara: Pegem Akademi.

Cameron,L.(2001). Teaching languages to young learners. Cambridge: Cambridge University Press.

Carter, R.\& McCarthy, M.(Eds). (1988) Vocabulary and language teaching. London: Longman.

Çıtak, B. (2003). Drama yoluyla çocuklara İngilizce drama öğretimi. Yayımlanmamış yüksek lisans tezi, Gazi Üniversitesi Eğitim Bilimleri Enstitüsü, Ankara.

Cotrell, J. (1987). Creative drama in the classroom grades 4-6. Teacher's resource book for theatre arts. National Textbook Co: Lincolnwood.

Demirel, Ö. (2004). Yabancı dil ögretimi. Ankara: Pegem Yayıncılık.

Dodson, S. (2000). Learning languages through drama. Texas Foreign Language Conference, Texas, 15.

Dupont, S.A (1992). The effectiveness of creative drama as an instructional strategy to enhance the reading comprehension skills of fifth-grade remedial readers. Reading research and Instruction, Volume 31, Issue 3.

Erion, P. (1997) Drama in the classroom. USA: Thomson-Shore, Inc.

Field, A. (2005) Discovering statistic using SPSS. London: Sage Publications.

Furman, L. (2000). In support of drama in early childhood education, again, Early Childhood Education Journal, 27(3), 173-178.

Flynn, R. \& G. Carr (1994). Exploring classroom literature through drama: a specialist and a teacher collaborate. Language Arts, Vol.71, 15-18. 
Gaudart, H. (1990). Using drama techniques in language teaching. Language Teaching Methodology for the Nineties, Anthology Series, 24, 11.

Hamilton, J. (1993). Drama in the language classroom. Centre for Information on Language Teaching and Research, London, 6-18.

Heathcote, D. (1972). Collected writings on education and drama in education 1: The Annual Survey. E. Johnson and C. O'Neill (Eds) Dorothy Heathcote. London: Pitman.

Karamanoğlu, Ş.Ş. (1999). İngilizce öğretiminde yaratıcı drama uygulamalarının hedef sözcük bilgisi ve hatırlamaya etkisi. Yayımlanmamış yüksek lisans tezi, Uludağ Üniversitesi, Bursa.

McCaslin, N. (1990). Creative drama in the classroom. New York: Addison-Wesley Publishing.

Özbahar,S. Y. (2007). Yaratıcı drama ile İngilizcede sözcük öğretimi. Çağdaş Drama Derneği Yaratıcı Drama Liderlik/Eğitmenlik Programı Yayımlanmamış Bitirme Projesi, Ankara.

Sierra, Z. (1997). Children's voices through dramatic play. Creative Drama Magazine: Multicultural Theatre, 2(4), 12-19.

Sinatra, R \& J.Gemake (1983). Using the right brain in the language arts. Illinois: Charles C.Thomas Publisher.

Pinciotti, P. (2000). Creative drama and young children: the dramatic learning connection, Arts Education Policy Review, 4-23.

Philips, S. (1999). Drama with children. Oxford: Oxford University Press.

Rittenberg, M. \& Kreitzer, P. (1981). English through drama: an introduction to language learning activities. England: The Alemay Press.

Whiteson, V. (1996). New ways of using drama and literature in language teaching. Bloomington: IL Heinemann.

Yassa, N.(1999). High school students' involvement in creative drama: the effects on social interaction. Research in Drama and Theatre in Education, 4(1), 37-51. 


\section{Ek 1. Atölye Planı Örneği}

Konu: Oyuncaklar- train (tren), plane (uçak), doll (oyuncak bebek), puppet (kukla), teddy bear (oyuncak ayı), ball (top)

Sınıf: 3. sınıf öğrencileri

Grup: 28 kişi

Süre: 2 saat

Yer: Gazi Üniversitesi Vakfı Özel İlköğretim Ana Okulu Ahşap Ev Sınıfı

Araç-gereçler: tren, uçak, oyuncak bebek, kukla, oyuncak ayı, asker, top, renkli kartonlar, renkli kalemler, oyuncak müze fotoğrafları, örtü, çalışma kağıdı

Yöntem: Yaratıcı Drama

Teknikler: Rol oynama, doğaçlama

\section{Kazanımlar}

İngilizce oyuncaklarla ilgili sözcükleri bilir.

Oyuncak müzelerinin farkına varır.

\section{Süreç}

\section{A- Hazırlık -Isınma}

\section{Etkinlik}

Öğrenciler çember oluşturup yere otururlar. Öğretmen, öğrencilere gözlerini kapatmalarını ve öğretmenlerinin ellerine vereceği nesneyi tahmin etmeye çalışmalarını söyler. Öğretmen sırayla öğrencilere oyuncakları verir. Bütün oyuncakları verdikten sonra öğrencilere oyuncakların neler olduğunu sorar. Oyuncaklar aynı sırayla öğrencilere tekrar verilir. Oyuncağı alan öğrenciden o oyuncak hakkında İngilizce bir sözcük bir söylemesini ve oyuncağı yanındaki arkadaşına vermesini ister.

\section{Etkinlik}

Öğretmen, oyuncakları sırayla gösterir ve İngilizce karşılığını söyler, öğrencilerden tekrar etmelerini ister. Oyuncaklarla beraber sözcük kartını da gösterir. Daha sonra sözcük kartlarını ve oyuncakları çemberin ortasına koyar ve gönüllü öğrencilerden nesnelerle resimleri eşleştirmeleri ister.

\section{Etkinlik}

Oyuncaklar masanın üstüne konur ve üstüne bir örtü örtülür. Gönüllü bir öğrenci bir oyuncağı örtünün altından eline alır ve "What am I holding?" diye arkadaşlarına sorar. Öğrenciler tutulan oyuncağı bulmaya yönelik İngilizce sorular sorarlar. Üç soru sorulduktan sonra öğrenciler tahminde bulunabilirler. Doğru tahminde bulunan kişi bu kez oyuncağı tutan kişi olur ve oyun 3-4 kere oynanır. Öğretmen bu etkinlik sırasında öğrencilerin sözcüklerin İngilizce karşılığıyla oyuncakları doğru eşleştirip eşleştiremediğini gözlemler.

\section{B- Canlandırma}

\section{Etkinlik}

Öğrencilere bulundukları yere oturmaları söylenir ve slaytlarla bazı oyuncak müzelerinden çekilmiş fotoğraflar gösterilir. Öğretmen, öğrencilere fotoğraflardaki gibi bir oyuncak müzesinde, masada duran oyuncaklardan biri olduklarını hayal etmelerini ister. Herkes vücutları ile müzede oldukları oyuncakları donuk imge olarak katılımcılara gösterir. Öğretmen öğrencilerin arasında dolaşır, omzuna dokunan öğrenci katılımcıların hangi oyuncak olduğunu inceler, bir arkadaşını seçerek tahtaya ismini ve hangi oyuncak olduğunu İngilizce yazar. Daha sonra bu öğrenciler kendi yerlerini ve formlarını alır, öğretmen başka öğrencilerin omuzlarına dokunur. Aynı fikirde olan öğrenciler tahtaya önceden yazılmış isimlerin yanına artı koyar. Herkesin ismi yazıldıktan sonra öğrenciler tahtaya bakarlar ve kendi ile tahminin doğru olup olmadığını kontrol ederler. Yapılan tahminler doğruysa kendi ismini ve İngilizce sözcüğü daire içine alır, yanlışsa ne olduğunu isminin yanına yazar. 


\section{Etkinlik}

Öğretmen, öğrencileri 1-2-3-4 diye sayarak 4 kişilik 6 grup yapar. Öğretmen, öğrencilere yeni bir oyuncak müzesinin kurulduğunu ve her birinin bu müzeye getirilen oyuncaklar olduğunu söyler. Öğrencilere hazırlıklarını yaparken bu oyuncakların kimlere ait olduğunu, neden müzeye getirildiklerini, kendilerini nasıl hissettiklerini düşünmeleri ve canlandırmalarında bunlara değinmeleri söylenir. Grupların canlandırmaları izlendikten sonra gruplara karton ve renkli kalemler verilir. Öğrenciler kendi oyuncak müzelerini ve oyuncaklarını çizerler, yanına ya da üstüne oyuncakların İngilizce karşılıklarını yazarlar. Yapılan müze resimleri duvara asılir.

\section{C- Değerlendirme}

\section{Etkinlik}

Öğrenciler çember kurarak otururlar. Öğretmen bugün yapılan oturumla ilgili herkesin bir sözcük söyleyeceğini ve elindeki topu yanındaki kişiye vereceğini söyler. Öğretmen yapılan çalışmalarda öğrencilerin neler hissettiklerini, sürecin nasıl olduğunu, nerelerde eğlenip nerelerde sıkıldıklarını sorar.

\section{Etkinlik}

Öğrenciler A-B diyerek ikili grup olurlar. Her gruba çalışmada öğrenilen sözcükleri içeren bir çalışma kâğıdı verilir. Çalışma kâğıdında iki bölüm vardır. Birinci bölümde oyuncakların resmi vardır ve öğrencilerden her resmin yanına İngilizce karşılığının yazılması istenir. İkinci bölümde "What's your favourite toy?" (en çok sevdiğin oyuncak nedir?) sorusuna öğrenciler oyuncaklarının resimlerini çizerek cevap verirler. Öğrenciler çalışma kâğıdını beraber yapar ve daha sonra cevaplar grup olarak kontrol edilir. 